Bidik: Jurnal Pengabdian kepada Masyarakat |Vol. 2 No. 1 Oktober 2021

Doi: https://doi.org/10.31849/bidik.v2i1.8188

\title{
Pengenalan dan Pelatihan Sistem Pengarsipan Elektronik Berbasis Web Untuk Alumni Prodi Ilmu Perpustakaan Fakultas Ilmu Budaya Unilak
}

\author{
Rismayeti*, Eko Noprianto \\ Prodi Ilmu Perpustakaan, Fakultas Ilmu Budaya, Universitas Lancang Kuning \\ *Email: rismayeti@gmail.com
}

\begin{abstract}
This service activity aims to provide introduction and training to Alumni Ilmu Perpustakaan Fakultas Ilmu Budaya Universitas Lancang Kuning, especially those who are already working. A common problem for partners is that they do not have adequate skills in managing Web-based Electronic Archives. The implementation of this service is expected to improve the understanding and skills of Alumni Ilmu Perpustakaan Fakultas Ilmu Budaya Universitas Lancang Kuning on how to manage Web-based electronic archives. The output produced in accordance with this activity plan is in the form of scientific articles. The method of implementing the activity is counseling. Submission of material is carried out by Lecturers who are members of the team proposing online community service activities.
\end{abstract}

Keywords: Filing System, Electronic Archive, Alumni.

\begin{abstract}
Abstrak
Kegiatan pengabdian ini bertujuan untuk memberikan pengenalan dan pelatihan kepada Alumni Prodi Ilmu Perpustakaan Fakultas Ilmu Budaya Universitas Lancang Kuning terutama yang sudah bekerja. Permasalahan umum pihak mitra ialah belum memiliki keterampilan yang memadai dalam mengelola Arsip Elektronik berbasis Web. Dilaksanakannya pengabdian ini diharapkan dapat meningkatkan pemahaman dan dan keterampilan Alumni Prodi Ilmu Perpustakaan Fakultas Ilmu Budaya Universitas Lancang Kuning tentang bagaimana mengelola arsip elektronik berbasis Web. Luaran yang dihasilkan sesuai dengan rencana kegiatan ini yaitu berupa artikel ilmiah.Adapun metode pelaksanaan kegiatan ialah penyuluhan. Penyampaian materi dilakukan oleh Dosen yang tergabung dalam tim pengusul kegiatan pengabdian kepada masyarakat secara daring.
\end{abstract}

Kata kunci : Sistem Pengarsipan, Arsip Elektronik, Alumni.

\section{Pendahuluan}

Berbicara tentang Arsip Dinamis Elektronik tidak terlapas dari dokumen elektronik sedangkan keberadaan dokumen elektronik tidak terlepas dari tekknologi informasi.Teknologi Informasi di sini adalah teknologi untuk mengolah, menyimpan, temu kembali serta penyebaran informasi.

Pada teknologi informasi terdapat dua komponen utama, yaitu computer dan telekomunikasi.Secara sederhana computer adalah mesin hitung yang mampu menjalankan tugasnya 
dengan kecepatan tinggi yang terdiri dari tiga bagian utama yaitu masukan, pengolahan dan luaran.Tidak kalah pentingnya pengelolaan Arsip berbasis Web ini untuk memudahkan temu kembali arsip kapan saja diperlukan. Alumni ilmu perpustakaan selayaknya memiliki keterampilan dalam mengelola arsip dinamis secara elektronik berbasis Web.

\section{Metode Pelaksanaan}

\section{Metode Pelaksanaan}

Adapun metode pelaksanaan kegiatan ialah memberikan keterampilan dalam menggunakan Aplikasi Arsip Elektronik berbasis Web kepada Alumni Ilmu Perpustakaan Fakultas Ilmu Budaya Unilak. Penyampaian materi dilakukan oleh Dosen yang tergabung dalam tim pengusul kegiatan pengabdian kepada masyarakat. Selain itu kegiatan dalam rangka pengabdian kepada masyarakat menggunakan dua metode, yaitu 1) Ceramah atau penyuluhan. Dalam metode ini penceramah atau penyuluh menyampaikan materi tentang pengenalan dan pelatihan tentang Pengelolaan Arsip Elektronik Berbasis Web. Dalam kesempatan itu peserta dibebaskan untuk bertanya jawab dengan pemateri . Rincian dari metode ini ialah pemaparan mengenai Aplikasi yang digunakan untuk mengelola Arsip Elektronik Berbasis Web. 2) Dialog interaktif, dalam hal ini peserta diposisikan sebagai subjek yang dapat memberikan ulasan terkait Pengelolaan Arsip Elektronik berbasis Web. Dialog ini sebagai curah pendapat (brainstorming) dari peserta untuk memperoleh masukan berupa persoalan, aspirasi, usulan, gagasan dan solusi. 3) Penyebaran kuisioner sebelum dan sesudah dilaksanakannya pelatihan (kuisioner pretest dan posttest). Tujuan dilaksanakannya penyebaran kuisioner ini adalah untuk mendapatkan perbandingan pengetahuan dan wawasan peserta sebelum dan sesudah materi diberikan.

\section{Prosedur Kerja}

Prosedur kerja yang akan dilaksanakan dengan beberapa tahap, yaitu Pertama, tahap persiapan. Persiapan ini difokuskan dengan menyiapkan semua peralatan yang dibutuhkan untuk melaksanan kegiatan ini, studi literatur dan melakukan koordinasi dengan organisasi terkait untuk melakukan kegiatan.

Kedua, perancangan materi Pengenalan dan Pelatihan Sistem Pengelolaan Arsip Elektronik Berbasis Web untuk Alumni Prodi Ilmu Perpustakaan Fakultas Ilmu Budaya Unilak, dengan mempersiapkan materi yang akan disampailkan dalam kegiatan ini. Modul diberkan kepada Peserta melalui Zoom.

Ketiga, pelaksanaan dilakukan oleh tim pelaksana Pengabdian dari Universitas Lancang Kuning. Adapun yang menjadi ukuran keberhasilan kegiatan ini, yakni 1) Terwujudnya kerja sama antara pelaksana kegiatan dengan pihak mitra, 2) Jumlah peserta yang hadir minimal $50 \%$ dari undangan, 3) Adanya interaksi dua arah dalam kegiatan antara pembicara dan peserta, 4) Meningkatnya pemahaman peserta terkait dengan materi yang disampaikannya, 5) Peningkatan pemahaman peserta kegiatan diukur dengan penyebaran kuesioner sebelum dan sesudah kegiatan. 
Gambar 1. Pelaksanaan Kegiatan Pengabdian
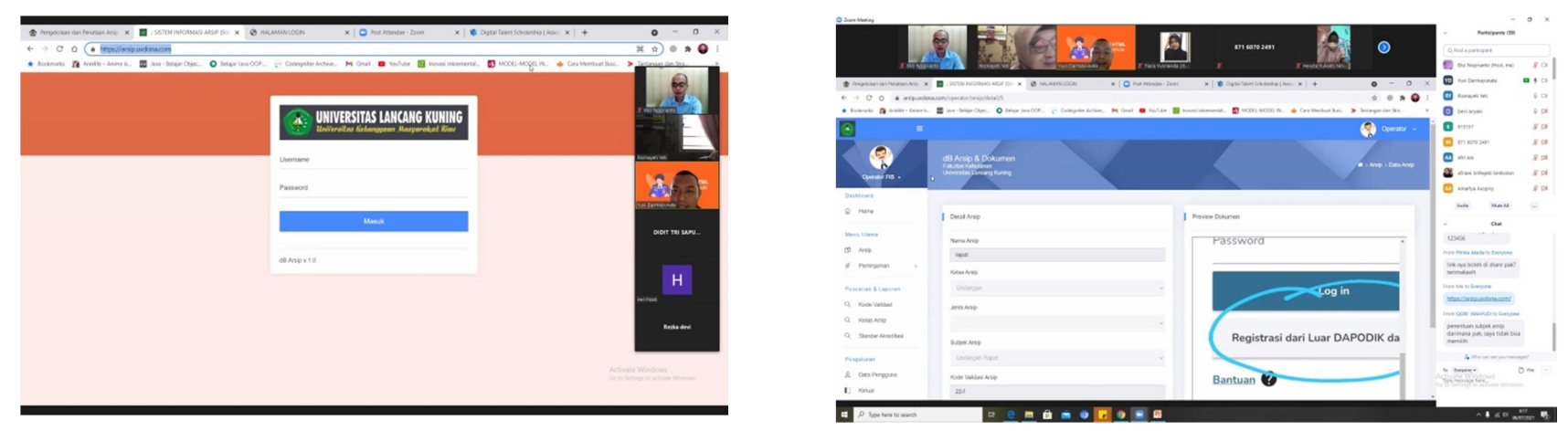

\section{Hasil dan Luaran yang Dicapai}

\section{H a s i 1}

Kegitan ini dilaksanakan secara daring menggunakan aplikasi Zoom Meeting pada tanggal 06 Juli 2021, yang diikuti oleh 49 orang peserta yang terdiri dari Alumni Prodi Ilmu Perpustakaan yang bekerja di perpustakaan sekolah dan Instansi Pemerintah maupun swasta yang ada di kota Pekanbaru. Kegiatan ini terlaksana dengan baik dan memperoleh beberapa hasil yang telah dicapai.

Tahap pertama, peserta diberikan kuesioner pretest melalui google form dan diberikan waktu selama 10 menit untuk mengisinya. Setelah itu dilanjutkan dengan kata pengantar dan penjelasan tentang "Pengenalan dan Pelatihan Arsip.

Tahap kedua, peserta menyimak pemaparan materi yang disampaikan oleh Tim Pengabdian yang berlansung selama 60 menit, dan dilanjutkan praktik penggunaan Aplikasi Arsip Elektronik Berbasis Web selama 120 menit.

Tahap ketiga, peserta diberikan kesempatan bertanya dan menyampaikan kendala yang dihadapi dalam menjalankan tugas sebagai Admin ataupun Arsiparis di instansi masingmasing

\section{Luaran yang Dicapai}

Evaluasi didapatkan dari hasil kuesioner yang diisi peserta sebelum dan sesudah pelatihan. Jawaban kuesioner ini menggambarkan bagaimana pemahaman peserta terhadap materi yang telah disajikan. Untuk lebih jelasnya dapat dilihat rekapitulasi jawaban peserta pada tabel berikut:

Tabel 1. Hasil Pretest dan Posttest

\begin{tabular}{|c|l|c|c|}
\hline No & \multicolumn{1}{|c|}{$\begin{array}{c}\text { Item } \\
\text { Pertanyaan }\end{array}$} & Pretest & Posttest \\
\hline 1 & $\begin{array}{l}\text { Apakah Anda pernah mendengar tentang arsip atau } \\
\text { kearsipan? }\end{array}$ & $94,9 \%$ & $100 \%$ \\
\hline 2 & $\begin{array}{l}\text { Apakah anda pernah mengikuti pelatihan tentang } \\
\text { arsip ataupun kearsipan? }\end{array}$ & $29,5 \%$ & $55,1 \%$ \\
\hline
\end{tabular}


Bidik Vol. 2 No. 1 Oktober 2021

\begin{tabular}{|c|l|c|c|}
\hline 3 & $\begin{array}{l}\text { Apakah anda pernah mengikuti pelatihan } \\
\text { pengarsipan elektronik berbasis web? }\end{array}$ & $7,7 \%$ & $44,9 \%$ \\
\hline 4 & $\begin{array}{l}\text { Apakah anda memahami tentang sistem } \\
\text { pengarsipan elektronik berbasis web? }\end{array}$ & $12,8 \%$ & $46.9 \%$ \\
\hline 5 & $\begin{array}{l}\text { Apakah anda memahami penggunaan aplikasi } \\
\text { pengarsipan elektronik berbasis web? }\end{array}$ & $11,5 \%$ & $46,9 \%$ \\
\hline
\end{tabular}

Dari hasil post test untuk 49 peserta $(100 \%)$ peserta pernah mendengar dan sekaligus telah mengikuti pelatihan ini. Setelah mengikuti pelatihan ini terlihat adanya peningkatan pemahaman dari pelaksanaan pelatihan ini, mereka mengerti dan memahami perangkat dan pengelolaan arsip elektronik.

\section{Simpulan dan Saran Simpulan}

Pelatihan ini bermanfaat bagi peserta baik sebagai admin maupun tata usaha sekolah dalam mengelola arsip dan dokumen di perpustakaan ataupun di sekolah dimana mereka bekerja. Terbukti dengan hasil pretest dan posttest menunjukkan terdapat peningkatan pemahaman tentang Arsip eklektronik dengan sistem pengarsipan berbasis Web, $50 \%$ dari mereka mengerti dan mampu dan akan menerapkan sistem pengarsipan yang sudah diberikan pada pelatihan ini. Pelatihan ini sangat bermanfaat sekali bagi mereka yang mengikutinya dan instansi yang mereka naungi.

\section{Saran}

Setelah pelatihan ini dilaksanakan diharapkan kepada peserta dapat mempraktekkan atau menggunakan sistem pengelolaan Arsip Elektronik ini di instansi tempat bekerja mereka masingmasing. Diharapkan juga mereka bisa bergabung dalam satu Group di medsos agar bisa saling mengisi dan berbagi pengetahuan dan pengalaman.

\section{Daftar Pustaka}

Amsyah, Zulkifli. (1996). Manajemen Kearsipan. Jakarta: Gramedia Pustaka Utama.

Barthos Basir. (1997). Manajemen Kearsipan Untuk Lembaga Negara, Swasta dan Perguruan Tinggi. Jakarta: Bumi Aksara.

Bafadal, Ibrahim. (2005). Pengelolaan Perpustakaan Sekolah. Jakarta: Bumi Aksara.

Dian Sinaga. (2011). Mengelola Perpustakaan Sekolah. Bandung: Bejana.

Martoatmojo. (1999). Pelayanan Baban Pustaka. Jakarta: Universitas Terbuka.

Permen Dalam Negeri No. 78 tahun 2012 tentang Pengelolaan Kearsipan Daerah, Kabupaten dan Kota. Sutarno NS (2006). Manajemen Perustakaan: Suatu Pendekatan Praktis. Jakarta: Sagung Seto.

Sugiarto Agus, Teguh Wahyono. (2010). Manajemen Kearsipan Moderen, Yogyakarta: Gava Media.

Sulistyo-Basuki. (1996). Pengantar Kearsipan. Jakarta : UT.

. (2010). Administrasi Arsip Sebuah Pengantar Memahami Arsip mulai dari prinsip sampai ke profesi, Hingga Penerimaan sampai ke Jasa Kearsipan. Jakarta.

Undang-Undang Republik Indonesia Nomor 43 Tahun 2009, Tentang Kearsipan. 
Permen Dalam Negeri No. 78 tahun 2012 tentang Pengelolaan Kearsipan Daerah, Kabupaten dan Kota. Wursanto. (1991). Kearsipan 1 dan 2. Yogyakarta : Kanisius. 